\title{
Analiza czynników metodycznych w aspekcie wyznaczania minimalnej gęstości objętościowej szkieletu gruntowego w świetle normy PN-B-04481:1988
}

\author{
Małgorzata Wszędyrówny-Nast ${ }^{1}$, Wojciech Tymiński ${ }^{2}$
}

\begin{abstract}
Analysis of methodological factors in determining the minimum dry density acc. to the standard PN-B-04481:1988. Prz. Geol., 69: 909-915; doi: 10.7306/2021.52

A b s t r a c t. The paper presents results of interlaboratory comparative test programme. The minimum dry density tests were performed according to PN-B-04481:1988, for four different sands and two types of solid-glass beads, by two laboratories, seven lab workers, using nine different types of funnel. The aim of this research is analysis of the results of the determination of minimum dry density to clarify the provisions of the standard PN-B-04481:1988. The main objectives are to: determine the influence of the geometry of the funnel used to test the minimum dry density on the test results; analyse the human factor on the test results; try to determine the geometrical criteria for funnels used to test the minimum dry density.
\end{abstract}

Keywords: minimum dry density, laboratory tests, interlaboratory comparative test, density determination

Wartości maksymalnej i minimalnej gęstości objętościowej szkieletu gruntowego $\left(\rho_{\mathrm{dmin}}, \rho_{\mathrm{dmax}}\right)$ wykorzystuje się w praktyce inżynierskiej podczas określania stopnia zagęszczenia $\left(\mathrm{I}_{\mathrm{D}}\right)$ gruntów niespoistych, a także w analizach zagadnienia upłynnienia gruntu. Zakłada się, że wartości gęstości objętościowej szkieletu gruntowego (minimalnej i maksymalnej) odnoszą się do warunków zagęszczania, w których grunt jest w stanie suchy.

Zagadnienie to analizowane jest od lat 30. XX w. Burmister w 1938 r. wskazał, że gęstość każdego gruboziarnistego gruntu mieści się pomiędzy dwoma granicami stanem luźnym i bardzo zagęszczonym. Określił on, że stan luźny uzyskuje się poprzez napełnianie pojemnika za pomocą lejka cienkimi warstwami bez zagęszczania, umożliwiając powolny wypływ materiału z lejka. Próbę zbadania niektórych czynników sedymentacyjnych decydujących o porowatości piasków, a w szczególności znalezienia metod określania porowatości granicznej dla danego piasku, podjął Kolbuszewski (1948). Wyniki swoich czteroletnich badań przeprowadzonych na Imperial College przedstawił w swojej pracy doktorskiej (Kolbuszewski, 1948). W kolejnych latach powstało wiele publikacji, w których były analizowane czynniki wpływające na uzyskiwane wartości minimalnej i maksymalnej gęstości objętościowej szkieletu gruntowego - zarówno te związane z metodyką wyznaczania tych wartości, jak i z samym gruntem (Youd, 1973; Selig, Ladd, 1973; Cubrinovski, Ishihara, 2002).

Z punktu widzenia inżynierskiego wartość stopnia zagęszczenia jest wiązana $\mathrm{z}$ właściwościami mechanicznymi badanego ośrodka. Prawidłowe wyznaczenie wartości granicznych zagęszczenia $\left(\rho_{\mathrm{dmax}}, \rho_{\mathrm{dmin}}\right)$ jest bardzo istotne z punktu widzenia właściwego scharakteryzowania warstw geotechnicznych pod względem parametrów wytrzymałościowych i odkształceniowych. Wyznaczenie parametrów wytrzymałościowych i odkształceniowych gruntów niespoistych w laboratorium, w aparacie trójosiowego ściskania wymaga przeprowadzenia rekonstrukcji próbek. Próbki rekonstruuje się w formach, najczęściej do zagęsz- czenia odpowiadającego warunkom in situ lub innego, w zależności od analizowanego zagadnienia inżynierskiego. W tym celu niezbędna jest znajomość wartości minimalnej i maksymalnej gęstości objętościowej szkieletu gruntowego. Zgodnie z PN-B-04481:1988 wartości te wyznacza się dla materiału suchego. Jednak sposób i warunki depozycji materiału mają wpływ na uzyskiwane wartości minimalnej gęstości objętościowej szkieletu gruntowego. W warunkach naturalnych (np. gdy sedymentacja gruntu zachodzi w ośrodku w pełni nasyconym) wartość minimalnej gęstości objętościowej szkieletu gruntowego (maksymalnego wskaźnika porowatości) różni się od wartości uzyskiwanych w warunkach laboratoryjnych (Lipiński, 2013). Należy tu zwrócić uwagę, że sposób depozycji ma również wpływ na dalsze zachowanie się materiału pod wpływem przykładanego obciążenia. Inne charakterystyki ściśliwości otrzyma się podczas zastosowania metod rekonstrukcji na sucho, na mokro i przy zagęszczaniu wilgotnego gruntu w warstwach (Lipiński, 2013).

Prowadzone są projekty mające na celu porównanie procedur badawczych stosowanych w różnych krajach oraz ujednolicenie metody badawczej (Blaker i in., 2015; Lunne i in., 2019). W Polsce dokumentem normatywnym, wg którego określa się maksymalną i minimalną gęstość objętościową szkieletu gruntowego jest norma PN-B04481:1988 p. 5.2.7. Ma ona status normy wycofanej, jednak wśród norm ISO 17892 (norm dotyczących laboratoryjnych badań gruntów zalecanych przez PN-EN 19972:2009 Eurokod 7) nie znalazła się procedura opisująca wyznaczanie parametrów maksymalnej i minimalnej gęstości objętościowej szkieletu gruntowego. W związku z tym wciąż stosuje się procedurę opisaną w normie PN-B04481:1988. Metoda wyznaczania minimalnej gęstości objętościowej szkieletu gruntowego opisana ww. normie jest w wielu aspektach niedoprecyzowana. Sposób oznaczenia tego parametru opiera się usypywaniu przez lejek suchego gruntu w cylindrze. Lejek należy podnosić w ten sposób, aby wydostający się z niego suchy grunt usypywał

\footnotetext{
${ }^{1}$ Instytut Techniki Budowlanej, Zakład Konstrukcji Budowlanych, Geotechniki i Betonu, ul. Ksawerów 21, 02-656 Warszawa; m.wszedyrowny@itb.pl

${ }^{2}$ Geoteko Projekty i Konsultacje Geotechniczne Sp. z o.o., ul. Wałbrzyska 14/16, 02-739 Warszawa; wojciech.tyminski@geoteko.com.pl
} 
się jak najluźniej. Z zagadnień, które nie są doprecyzowane w wyżej wymienionej normie, a mogących mieć wpływ na oznaczenie minimalnej gęstości objętościowej szkieletu gruntowego, można wymienić:

- brak zdefiniowanej geometrii lejka, który powinien być użyty do badania (wysokość, średnica, kąt nachylenia $\alpha$, średnica otworu wylotowego $\varnothing$ ),

- brak określonego materiału, z jakiego powinien być wykonany lejek,

- brak jednoznacznych wymiarów cylindra (wysokości), w którym usypuje się badany grunt.

Ponadto, na podstawie wcześniejszych obserwacji autorów, wpływ czynnika ludzkiego sprawia, że badanie to jest subiektywne, tzn. na podstawie porównań wewnątrzi międzylaboratoryjnych obserwuje się różnice pomiędzy wynikami uzyskanymi z badań wykonanych przez różne osoby.

W przypadku określenia niepewności pomiarowej czy kryteriów stosowanych w porównaniach międzylaboratoryjnych, doprecyzowanie powyższych czynników może mieć istotne znaczenie.

Celem pracy było zwrócenie uwagi na potrzebę doprecyzowania metodyki badań podanej w normie PN-B04481:1988 w zakresie oznaczania minimalnej gęstości objętościowej szkieletu gruntowego, tj. określenie wpływu geometrii lejka zastosowanego do badań minimalnej gęstości objętościowej szkieletu gruntowego na uzyskiwane wyniki badań dla różnych materiałów, przeanalizowanie czynnika ludzkiego na uzyskiwane wyniki badań oraz próba określenia kryteriów geometrycznych dla lejków stosowanych do badań minimalnej gęstości objętościowej szkieletu gruntowego.

\section{MATERIAŁ I METODY}

Badania wykonane zostały zgodnie z normą PN-B04481:1988 p. 5.2.7 przez dwa laboratoria posiadające akredytację na to badanie. Stosowano różne rodzaje materiałów (cztery rodzaje gruntu oraz dwa rodzaje granulatu szklanego o jednorodnym uziarnieniu ) i plastikowe lejki o różnych kątach nachylenia tworzącej stożka $\alpha$ i średnicach otworu wylotowego $\varnothing$. Każdy z lejków sięgał podstawy cylindra, w którym wykonuje się oznaczenie minimalnej gęstości objętościowej oraz miał objętość umożliwiającą umieszczenie w nim ilości gruntu wystarczającej do wypełnienia całego cylindra, bez konieczności dosypywania gruntu w czasie badania. Sześć lejków zostało zakupionych, trzy - wydrukowane w technice druku 3D. Wewnętrzna powierzchnia wydrukowanych lejków została wypolerowana. W tabeli 1 przedstawiono zakres wykonanych prac.

Tab. 1. Zestawienie przeprowadzonych prac

Table 1. Summary of the tests

\begin{tabular}{|c|c|c|c|c|}
\hline $\begin{array}{l}\text { Laboratoria } \\
\text { wykonujące badania } \\
\text { Laboratories }\end{array}$ & $\begin{array}{l}\text { Wykonawcy } \\
\text { badań } \\
\text { Workers }\end{array}$ & $\begin{array}{c}\text { Wykaz próbek gruntów } \\
\text { i materiałów użytych do badań } \\
\text { Soil samples and materials used for the tests }\end{array}$ & $\begin{array}{c}\text { Liczba i geometria lejków } \\
\text { zastosowanych do badań } \\
\text { Number and dimensions } \\
\text { of funnels }\end{array}$ & $\begin{array}{c}\text { Liczba wykonanych } \\
\text { badań } \\
\text { Number of tests }\end{array}$ \\
\hline $\begin{array}{l}2 \text { laboratoria } \\
2 \text { laboratories }\end{array}$ & $\begin{array}{l}7 \text { wykonawców } \\
7 \text { contractors }\end{array}$ & $\begin{array}{c}4 \text { rodzaje gruntów, } \\
2 \text { rodzaje szklanych granulek } \\
4 \text { different soils, } \\
2 \text { types of solid-glass beads }\end{array}$ & $\begin{array}{l}9 \text { lejków } \\
9 \text { funnels }\end{array}$ & 526 \\
\hline $\begin{array}{l}\text { Laboratorium Badań } \\
\text { Konstrukcji } \\
\text { Budowlanych, } \\
\text { Geotechniki i Betonu } \\
\text { ITB } \\
\text { GEOTEKO Projekty } \\
\text { i Konsultacje } \\
\text { Geotechniczne } \\
\text { Sp. z o.o. }\end{array}$ & $\begin{array}{l}\text { ITB1 } \\
\text { ITB2 } \\
\text { ITB3 } \\
\text { G1 } \\
\text { G2 } \\
\text { G3 } \\
\text { G4 }\end{array}$ & $\begin{array}{l}1 \text { - piasek drobny / fine sand } \\
2 \text { - piasek średni } 1 / \text { medium sand } 1 \\
3 \text { - piasek średni } 2 \text { / medium sand } 2 \\
4 \text { - piasek gruby / coarse sand } \\
5 \text { - granulki szklane drobne }(0,6-0,8 \mathrm{~mm}) \\
\text { fine solid-glass beads }(0.6-0.8 \mathrm{~mm}) \\
6 \text { - granulki szklane grube }(0,85-1,2 \mathrm{~mm}) \\
\text { coarse solid-glass beads }(0.85-1.2 \mathrm{~mm})\end{array}$ & $\begin{array}{l}1-\alpha=10, \varnothing=11,45 \mathrm{~mm} \\
2-\alpha=10, \varnothing=21 \mathrm{~mm} \\
3-\alpha=10, \varnothing=24,85 \mathrm{~mm} \\
4-\alpha=10, \varnothing=26,8 \mathrm{~mm} \\
5-\alpha=10, \varnothing=27,7 \mathrm{~mm} \\
6-\alpha=9, \varnothing=10 \mathrm{~mm} \\
7-\alpha=9, \varnothing=12 \mathrm{~mm} \\
8-\alpha=45, \varnothing=12 \mathrm{~mm} \\
9-\alpha=12, \varnothing=4,76 \mathrm{~mm}\end{array}$ & \\
\hline
\end{tabular}

Tab. 2. Parametry charakteryzujące badane grunty i materiały

Table 2. Index properties of soils and materials

\begin{tabular}{|c|c|c|c|c|c|c|}
\hline \multirow{3}{*}{$\begin{array}{c}\text { Rodzaj badanego gruntu/materiału } \\
\text { Type of soil/material }\end{array}$} & \multirow{2}{*}{\multicolumn{3}{|c|}{$\begin{array}{l}\text { Zawartość procentowa frakcji } \\
\text { Fraction content }[\%]\end{array}$}} & \multicolumn{2}{|c|}{$\begin{array}{c}\text { Parametry charakteryzujące } \\
\text { uziarnienie } \\
\text { Grading characteristics }\end{array}$} & \multirow{3}{*}{$\begin{array}{c}\text { Gęstość wlaściwa } \\
\text { Particle density } \\
\rho_{\mathrm{s}}\left[\mathrm{Mg} / \mathrm{m}^{3}\right]\end{array}$} \\
\hline & & & & \multirow{2}{*}{$\begin{array}{c}\text { Wskaźnik } \\
\text { krzywizny } \\
\text { uziarnienia } \\
\text { Coefficient of } \\
\text { curvature }\end{array}$} & \multirow{2}{*}{$\begin{array}{c}\text { Wskaźnik } \\
\text { jednorodności } \\
\text { uziarnienia } \\
\text { Uniformity } \\
\text { coefficient } \\
\mathrm{Cu}[-]\end{array}$} & \\
\hline & $>2 \mathrm{~mm}$ & $>0,5 \mathrm{~mm}$ & $>0,25 \mathrm{~mm}$ & & & \\
\hline 1 - piasek drobny / fine sand & 0 & 3 & 18 & 1 & 2 & 2,68 \\
\hline 2 - piasek średni 1 / medium sand 1 & 0 & 37 & 92 & 1 & 2 & 2,67 \\
\hline 3 - piasek średni 2 / medium sand 2 & 0 & 0 & 59 & 1 & 2 & 2,67 \\
\hline 4 - piasek gruby / coarse sand & 0 & 68 & 84 & 1 & 5 & 2,66 \\
\hline $\begin{array}{l}5 \text { - granulki szklane drobne }(0,6-0,8 \mathrm{~mm}) \\
\text { fine solid-glass beads }(0.6-0.8 \mathrm{~mm})\end{array}$ & 0 & 100 & 100 & - & - & 2,51 \\
\hline $\begin{array}{l}6 \text { - granulki szklane grube }(0,85-1,2 \mathrm{~mm}) \\
\text { coarse solid-glass beads }(0.85-1.2 \mathrm{~mm})\end{array}$ & 0 & 100 & 100 & - & - & 2,59 \\
\hline
\end{tabular}




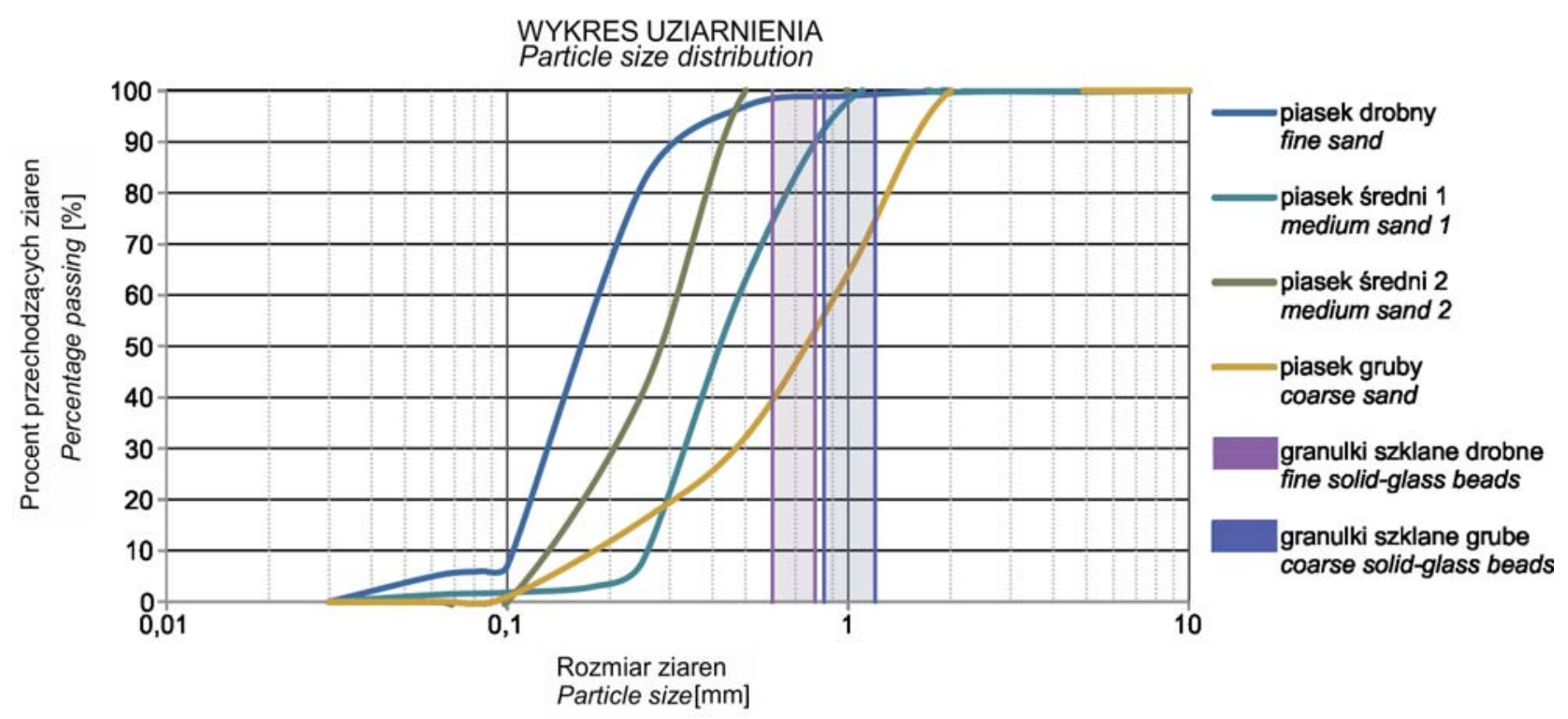

Ryc. 1. Krzywe uziarnienia badanych gruntów oraz materiałów

Fig. 1. Particle size distribution of tested soils and materials
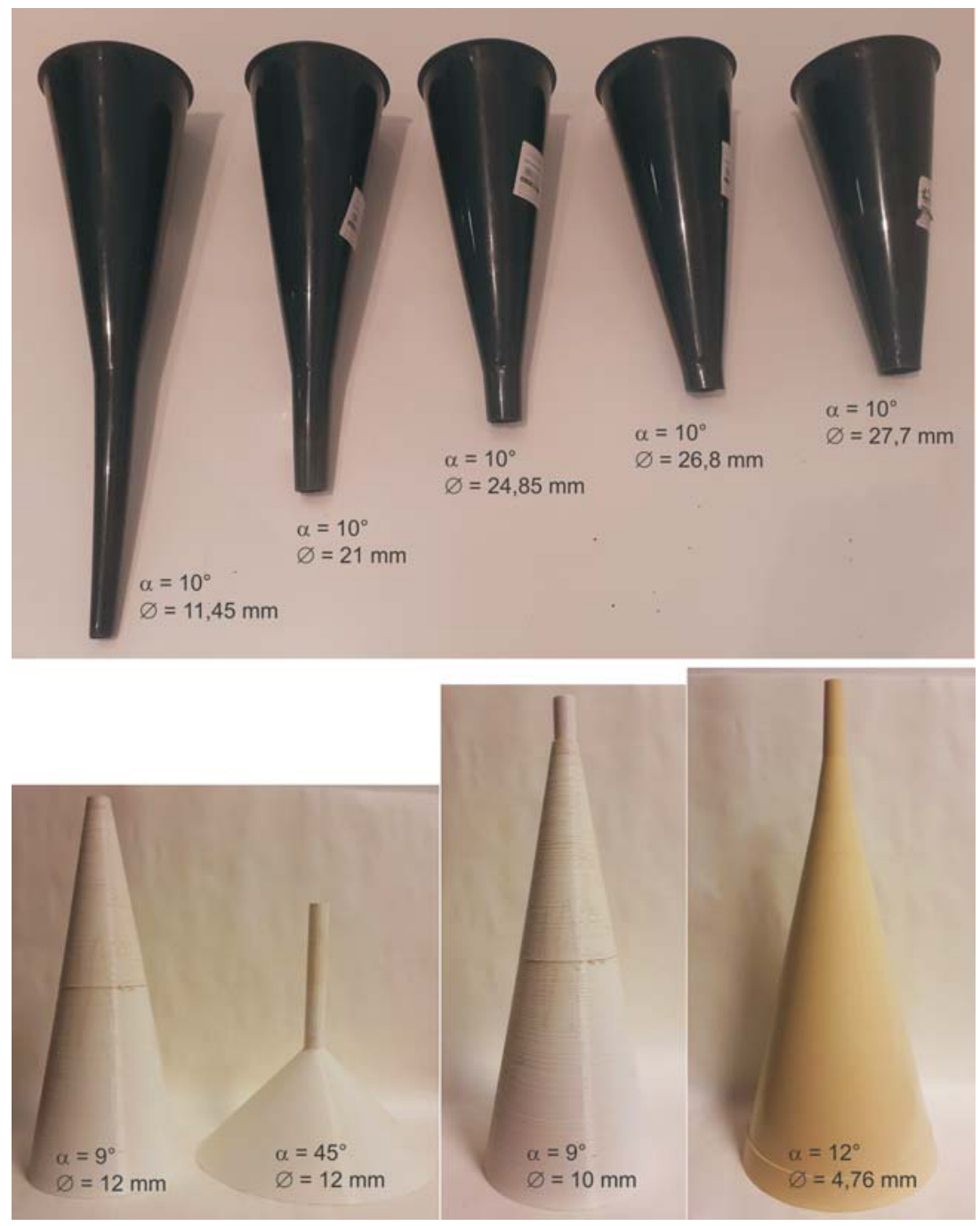

Ryc. 2. Plastikowe lejki wykorzystane do badań

Fig. 2. Plastic funnels used for testing

materiałów. Zdjęcia plastikowych lejków zastosowanych do badań przedstawiono na rycinie 2 .

\section{WYNIKI BADAŃ}

Wpływ średnicy wylotu lejka na uzyskiwane wartości minimalnej gęstości objętościowej szkieletu gruntowego dla badanych materiałów zaprezentowano na wykresach - ryciny $3-8$. Każdy wykonawca badań wykonał 5 oznaczeń minimalnej gęstości objętościowej dla danego rodzaju badanego materiału i lejka. Punkty na wykresach pokazują najniższą wartość uzyskaną przez danego wykonawcę w serii 5 oznaczeń przy użyciu danego lejka.

$\mathrm{Na}$ przykładzie piasku drobnego na rycinie 9 przedstawiono wpływ wysokości cylindra, w którym usypuje się grunt, na uzyskiwane wartości minimalnej gęstości objętościowej szkieletu gruntowego.

$\mathrm{Na}$ rycinie 10 zestawiono wartości minimalnej gęstości objętościowej szkieletu gruntowego uzyskane dla różnych badanych materiałów przy użyciu lejka $\alpha=9^{\circ} \varnothing=12 \mathrm{~mm}$ oraz lejka

Dla każdego gruntu oznaczono zawartość procentową frakcji oraz gęstość właściwą. W tabeli nr 2 zostały zaprezentowane parametry charakteryzujące badane grunty $\mathrm{i}$ materiały, a na rycinie 1 przedstawiono wykresy uziarnienia ba- danych gruntów oraz pole uziarnienia badanych $\alpha=45^{\circ} \varnothing=12 \mathrm{~mm}$.

Poniżej na rycinie 11 przedstawiono symulację - wpływ zmiany wartości minimalnej gęstości objętościowej szkieletu gruntowego na wartość stopnia zagęszczenia. W ramach realizacji opisywanych badań maksymalne różnice 

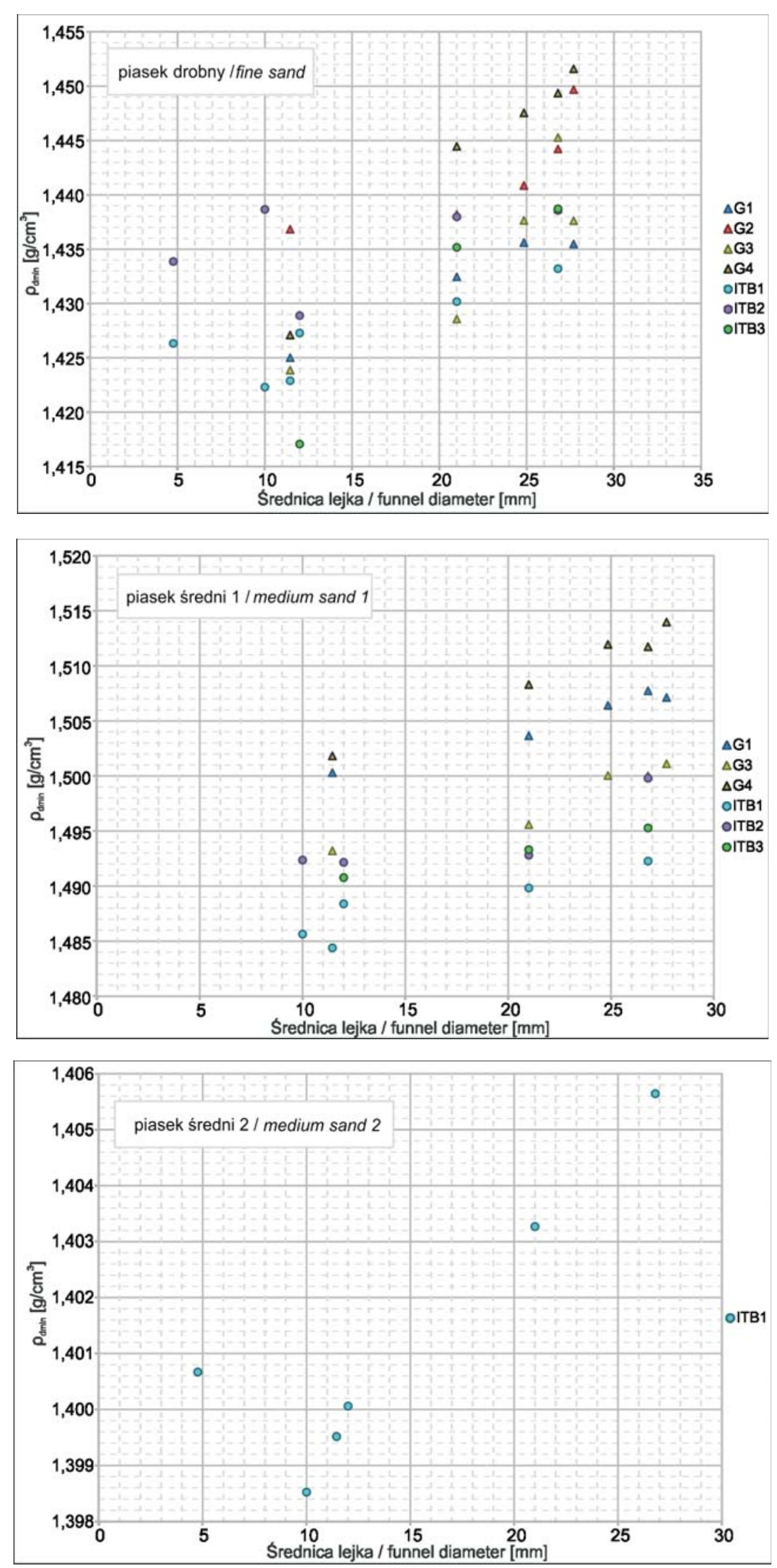

\section{$\leftarrow$}

Ryc. 3. Wpływ średnicy wylotu lejka na uzyskiwane wartości minimalnej gęstości objętościowej szkieletu gruntowego dla próbki 1 - piasek drobny

Fig. 3. The influence of funnel diameter on the minimum dry density results for sample 1 - fine sand $\leftarrow$

Ryc. 4. Wpływ średnicy wylotu lejka na uzyskiwane wartości minimalnej gęstości objętościowej szkieletu gruntowego dla próbki 2 - piasek średni 1

Fig. 4. The influence of funnel diameter on the minimum dry density results for sample 2 medium sand 1 otrzymanych wartości minimalnej gęstości objętościowej szkieletu gruntowego nie przekraczały wartości $0,025 \mathrm{~g} / \mathrm{cm}^{3}$. Jednak w celu graficznego zobrazowania tego, w jakich warunkach określenie stanu gruntu jest najbardziej wrażliwe na zmianę minimalnej gęstości objętościowej szkieletu gruntowego, na symulacji pokazano szerszy przedział zmienności $\rho_{\mathrm{dmin}}$. Jak widać, największy wpływ minimalnej gęstości objętościowej szkieletu gruntowego na błąd w określeniu stopnia zagęszczenia jest dla stanów najluźniejszych. 

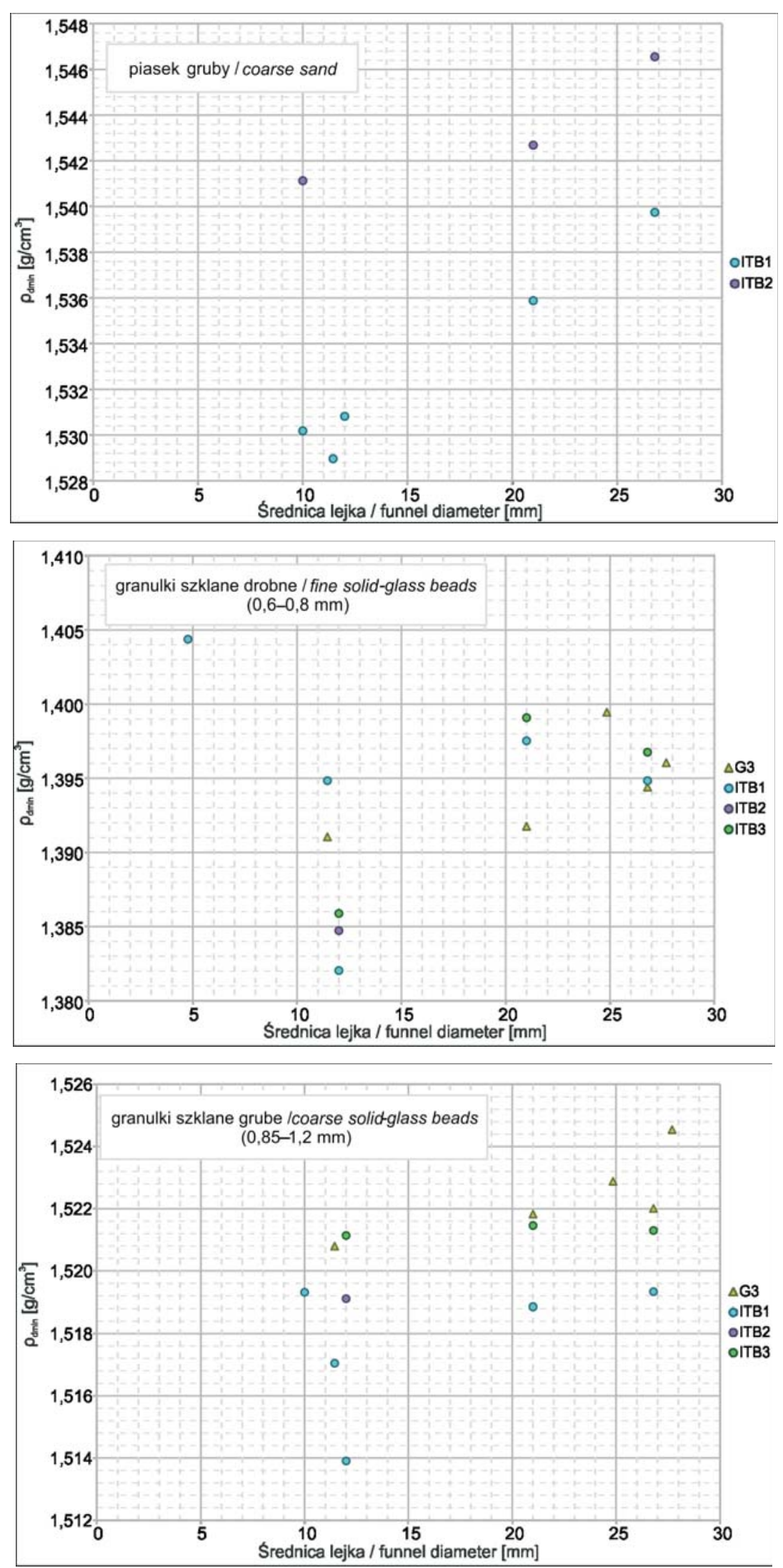

\section{$\leftarrow$}

Ryc. 6. Wpływ średnicy wylotu lejka na uzyskiwane wartości minimalnej gęstości objętościowej szkieletu gruntowego dla próbki 4 piasek gruby

Fig. 6. The influence of funnel diameter on the minimum dry density results for sample 4 coarse sand

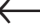

Ryc. 7. Wpływ średnicy wylotu lejka na uzyskiwane wartości minimalnej gęstości objętościowej szkieletu gruntowego dla próbki 5 granulki szklane drobne $(0,6-0,8 \mathrm{~mm})$

Fig. 7. The influence of funnel diameter on the minimum dry density results for sample 5 fine solid-glass beads $(0.6-0.8 \mathrm{~mm})$

\section{$\leftarrow$}

Ryc. 8. Wpływ średnicy wylotu lejka na uzyskiwane wartości minimalnej gęstości objętościowej szkieletu gruntowego dla próbki 6 granulki szklane grube $(0,85-1,2 \mathrm{~mm})$

Fig. 8. The influence of funnel diameter on the minimum dry density results for sample 6 - coarse solid-glass beads $(0.85-1.2 \mathrm{~mm})$

\section{WNIOSKI}

$\mathrm{Na}$ podstawie dotychczas przeprowadzonych badań i analiz można sformułować następujące wnioski:

- średnica otworu wylotu lejka wpływa na uzyskiwane wartości minimalnej gęstości objętościowej szkieletu grun- towego; wraz ze wzrostem średnicy wylotu lejka uzyskuje się większą wartość minimalnej gęstości objętościowej szkieletu gruntowego;

- lejek wykorzystywany do badań powinien mieć średnicę powyżej $5 \mathrm{~mm}$. Lejek o średnicy 4,76 $\mathrm{mm}$ stawał się niedrożny w trakcie badania, a wyniki, które udało się uzyskać dla drobnych materiałów były wyższe niż te uzyskane 

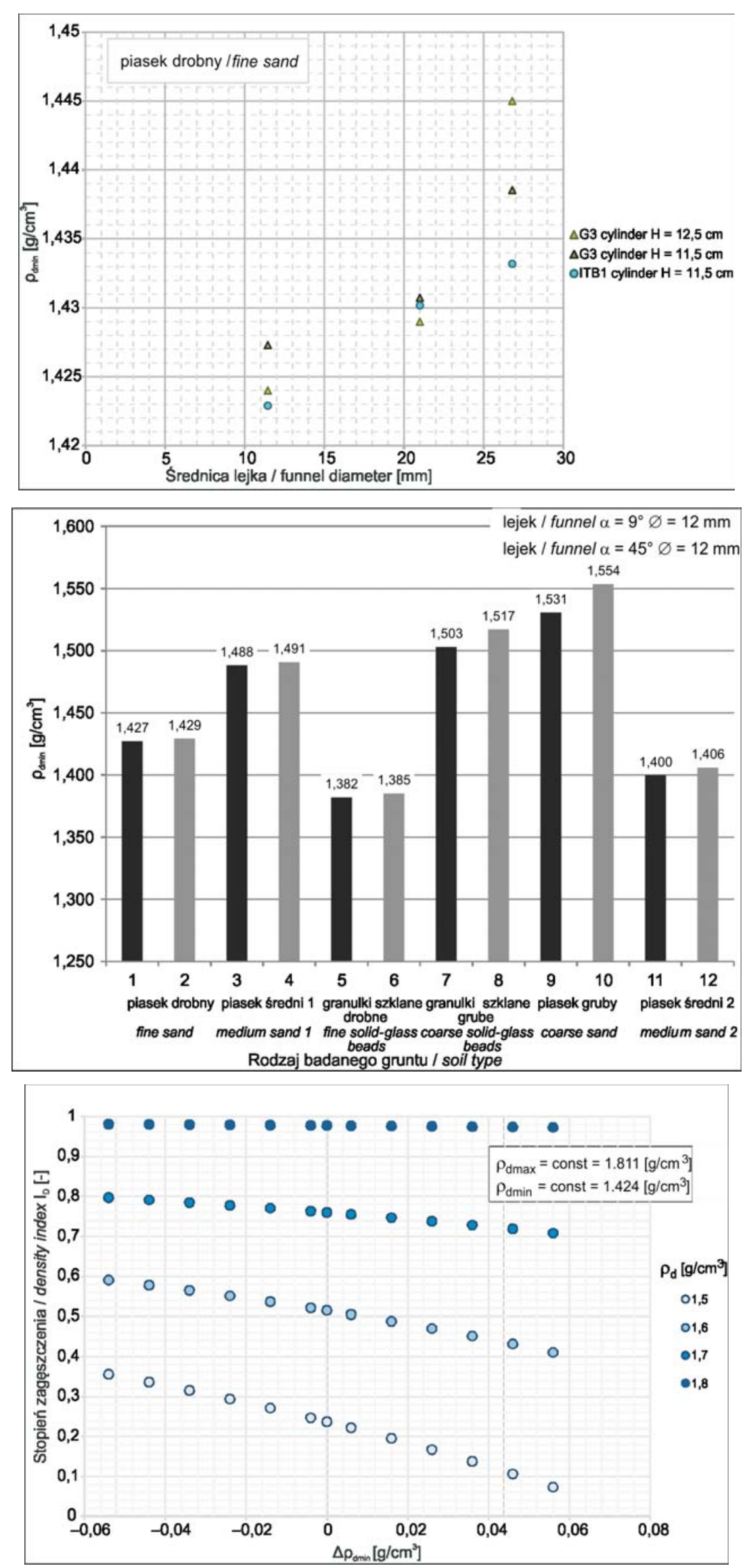

\section{$\leftarrow$}

Ryc. 9. Wpływ wysokości cylindra, w którym usypuje się grunt na uzyskiwane wartości minimalnej gęstości objętościowej szkieletu gruntowego

Fig. 9. The influence of height of the cylinder for soils on the minimum dry deisity results

Ryc. 10. Wpływ kąta nachylenia tworzacej lejka na uzyskiwane wartości minimalnej gęstości objętościowej szkieletu gruntowego Fig. 10. The influence of funnel inclination angle on the minimum dry density results

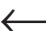

Ryc. 11. Symulacja - wpływ zmiany wartości minimalnej gęstości objętościowej szkieletu gruntowego na wartość stopnia zagęszczenia Fig. 11. Simulation - the effect of changing the minimum dry density on density index lejkiem o większej średnicy. Dodatkowo lejek powinien sięgać do dna cylindra i mieć objętość umożliwiającą umieszczenie w nim ilości gruntu wystarczającej do wypełnienia całego cylindra, bez konieczności dosypywa- nia gruntu w czasie badania. Grunt powinien być usypywany w osi cylindra, a nie po jego ściankach. Autorzy uważają, że średnica wylotu lejka powinna się zawierać w przedziale 10-12 mm. Dla takiej średnicy uzyskiwano 
Tab. 3. Maksymalne różnice w uzyskanych wartościach minimalnej gęstości objętościowej szkieletu gruntowego Table 3. Maximum differences in the values of dry density of solid particles

\begin{tabular}{|c|c|c|}
\hline \multirow{3}{*}{$\begin{array}{l}\text { Material } \\
\text { Material }\end{array}$} & \multicolumn{2}{|c|}{$\begin{array}{l}\text { Maksymalne różnice w uzyskanych wartościach minimalnej gęstości objętościowej } \\
\text { szkieletu gruntowego } \\
\text { Maximum differences in the minimum dry density results }\end{array}$} \\
\hline & $\begin{array}{l}\text { kryterium - pojedynczy wykonawca, } \\
\text { wiele średnic lejka } \\
\text { criterion - single lab worker, } \\
\text { many funnel diameters }\end{array}$ & $\begin{array}{c}\text { kryterium - pojedyncza średnica lejka, } \\
\text { wielu wykonawców } \\
\text { criterion - single funnel diameter, } \\
\text { many lab workers }\end{array}$ \\
\hline & {$\left[\mathrm{g} / \mathrm{cm}^{3}\right]$} & {$\left[\mathrm{g} / \mathrm{cm}^{3}\right]$} \\
\hline 1 - piasek drobny / fine sand & 0,025 & 0,017 \\
\hline 2 - piasek średni 1 / medium sand 1 & 0,012 & 0,018 \\
\hline 3 - piasek średni $2 /$ medium sand 2 & 0,007 & - \\
\hline 4 - piasek gruby / coarse sand & 0,011 & 0,011 \\
\hline $\begin{array}{l}5 \text { - granulki szklane drobne }(0,6-0,8 \mathrm{~mm}) \\
\text { fine solid-glass beads }(0.6-0.8 \mathrm{~mm})\end{array}$ & 0,022 & 0,007 \\
\hline $\begin{array}{l}6 \text { - granulki szklane grube }(0,85-1,2 \mathrm{~mm}) \\
\text { coarse solid-glass beads }(0.85-1.2 \mathrm{~mm})\end{array}$ & 0,005 & 0,007 \\
\hline
\end{tabular}

najniższe wartości gęstości objętościowej szkieletu gruntowego;

- w przypadku kulek o jednorodnym uziarnieniu wpływ średnicy wylotu lejka nie jest tak istotny jak w przypadku gruntów, jednak tendencja wpływu średnicy otworu na wynik pozostaje taka sama jak w przypadku gruntów;

- odnosząc się do celu projektu, można powiedzieć, że wpływ średnicy wylotu zastosowanego lejka jest większy niż czynnik ludzki. Maksymalne różnice w uzyskanych wartościach gęstości objętościowej szkieletu gruntowego zostały przedstawione w tabeli 3 .

- w przypadku piasków drobnych i średnich kąt nachylenia lejka nie jest tak istotny jak w przypadku piasków grubych. Maksymalna różnica w uzyskanych wartościach minimalnej gęstości objętościowej szkieletu gruntowego dla piasków drobnych i średnich wyniosła $0,006\left[\mathrm{~g} / \mathrm{cm}^{3}\right]$ natomiast dla piasku grubego $0,023\left[\mathrm{~g} / \mathrm{cm}^{3}\right]$. Niższe wartości uzyskano dla lejka o kącie nachylenia $\alpha=9^{\circ}$. Zaleca się stosowanie lejka o kącie nachylenia $\alpha$ z przedziału 9-10;

- największy wpływ minimalnej gęstości objętościowej szkieletu gruntowego na błąd w określeniu stopnia zagęszczenia jest dla stanów najluźniejszych. Jednak należy pamiętać, że wartość minimalnej gęstości objętościowej szkieletu gruntowego jest jednym z dwóch czynników wpływających na określenie stopnia zagęszczenia;

- przedział zmienności wyników wynikający z wykorzystania lejków i cylindrów o różnej geometrii jest większy niż niepewności pomiarowe. Błąd ten nie musi być potraktowany jako nieprawidłowe wykonanie badania wg normy PN-B-04481:1988 p. 5.2.7., ponieważ norma nie precyzuje wymagań dotyczących geometrii lejka i cylindra (o czym wspomniano na początku niniejszego artykułu). W związku z tym w przypadku wykonywania ocen zgod- ności lub określania stopnia zagęszczenia przez kilka laboratoriów można uzyskać kilka różnych wyników, a każdy z nich może być uznany jako wykonany poprawnie.

Autorzy podziękowania składają Recenzentom za cenne uwagi.

\section{LITERATURA}

BLAKER Ø., LUNNE T., VESTGÅRDEN T., KROGH L., THOMSEN N.V., POWELL J., WALLACE C.F. 2015 - Method dependency for determining maximum and minimum dry unit weights of sands. Proceedings of the 3rd International Symposium on Frontiers in Offshore Geotechnics (ISFOG 2015), 2: 1159-1166.

BURMISTER D.M. 1938 - Study of Physical Characteristics of Soils, with special reference to earth structures. Bull. Columbia Univ. Civ. Eng. Res. Lab., 6

CUBRINOVSKI M., ISHIHARA K. 2002 - Maximum and minimum void ratio characteristics of sands. Soils Found., 42 (6): 65-78.

KOLBUSZEWSKI J.J. 1948 - Research on packing and density of sands. $\mathrm{Ph} . \mathrm{D}$. Thesis. Imperial College of Science and Technology.

LIPIŃSKI M.J. 2013 - Kryteria wyznaczania parametrów geotechnicznych. Wydaw. SGGW, Warszawa.

LUNNE T., KNUDSEN S., BLAKER Ø, VESTGÅRDEN T., POWEL J., WALLACE C.F., KROGH L., THOMSEN N.V., YETGINER G., GHANEKAR R.K. 2019 - Methods used to determine maximum and minimum dry unit weights of sand: Is there a need for a new standard? Can. Geotech. J., 56: 1-18.

PN-B-04481:1988 Grunty budowlane. Badania próbek gruntu.

PN-EN 1997-2:2009 Eurokod 7: Projektowanie geotechniczne - Część 2: Rozpoznanie i badanie podłoża gruntowego.

SELIG E., LADD R. 1973 - Evaluation of Relative Density Measurements and Applications. Evaluation of Relative Density and its Role in Geotechnical Projects Involving Cohesionless Soils. West Conshohocken, PA: ASTM International: 487-504.

YOUD T. 1972 - Factors Controlling Maximum and Minimum Densities of Sands. ASTM Spec. Tech. Publ., 523: 98-112.

Praca wpłynęła do redakcji 15.06.2021 r.

Akceptowano do druku 19.07.2021 r. 